\title{
Amphotericin B Induces Glial Cell Line-Derived Neurotrophic Factor in the Rat Brain
}

\author{
Akiko MOTOYOSHI-YAMASHIRO' ${ }^{1)}$, Katsura TAKANO ${ }^{1) *}$, Kenji KAWABE $^{1)}$, Takeshi IZAWA ${ }^{2)}$, \\ Hidemitsu NAKAJIMA $^{3)}$, Mitsuaki MORIYAMA ${ }^{1)}$ and Yoichi NAKAMURA ${ }^{1)}$ \\ ${ }^{1)}$ Laboratory of Integrative Physiology in Veterinary Sciences, Graduate School of Life and Environmental Sciences, Osaka Prefecture \\ University, Osaka 598-8531, Japan \\ ${ }^{2)}$ Laboratory of Veterinary Pathology, Graduate School of Life and Environmental Sciences, Osaka Prefecture University, Osaka \\ 598-8531, Japan \\ ${ }^{3)}$ Laboratory of Veterinary Pharmacology, Graduate School of Life and Environmental Sciences, Osaka Prefecture University, Osaka \\ 598-8531, Japan
}

(Received 26 March 2014/Accepted 6 June 2014/Published online in J-STAGE 3 October 2014)

ABSTRAct. Amphotericin B (AmB) is a polyene antifungal drug and is reported to be one of a few reagents having therapeutic effects on prion diseases, that is, a delay in the appearance of clinical signs and prolongation of the survival time in an animal model. In prion diseases, glial cells have been suggested to play important roles; however, the therapeutic mechanism of AmB on prion diseases remains elusive. We have previously reported that $\mathrm{AmB}$ changed the expression of neurotrophic factors in microglia and astrocytes (Motoyoshi et al., 2008, Neurochem. Int. 52, 1290-1296; Motoyoshi-Yamashiro et al., 2013, ibid. 63, 93-100). These results suggested that neurotrophic factors derived from glial cells might be involved in the therapeutic mechanism of AmB. In the present study, we examined immunohistochemically the effects of $\mathrm{AmB}$ on the expression of neurotrophic factors in the rat brain. We found that direct injection of AmB into the striatum significantly enhanced the expression of glial cell line-derived neurotrophic factor protein. Amphotericin B also increased the expressions of $\mathrm{CD} 11 \mathrm{~b}$ and glial fibrillary acidic protein, markers of microglia and astrocytes, respectively. Moreover, expressions of the two neurotrophic factors by $\mathrm{AmB}$ were co-localized with the expression of $\mathrm{CD} 11 \mathrm{~b}$ or glial fibrillary acidic protein. These results suggest that AmB in vivo might also activate glial cells and induce the production of neurotrophic factors protecting neurons in prion diseases. KEY WORDS: amphotericin B, astrocytes, microglia, neurotrophic factors

doi: 10.1292/jvms.14-0160; J. Vet. Med. Sci. 76(10): 1353-1358, 2014

Amphotericin B (AmB), a polyene macrolide antibiotic, is an effective antifungal agent [4]. It has been reported to delay the appearance of experimental scrapie in hamsters infected intracerebrally or intraperitoneally with the $263 \mathrm{~K}$ scrapie strain [22]. Amphotericin B has also been reported to delay prion protein ( $\mathrm{PrP}$ ) accumulation and to inhibit gliosis in the brain [1], whereas the mechanism remains unclear.

The neuropathological features that characterize prion diseases, including bovine spongiform encephalopathy in the cow and scrapie in the sheep and goat, are the deposition of pathological prion protein ( $\mathrm{PrPsc}$ ), spongiform degeneration of neurons and gliosis involving activation of microglia and astrocytes $[12,30]$. In prion diseases, microglial activation was observed in mouse models of the disease before neuronal loss and subsequent clinical signs of the disease [31]. It also has been suggested that microglial activation causes astrocytic proliferations and results in gliosis [6], and glial cells have been reported to co-localize with PrPsc deposits

\footnotetext{
*Correspondence to: TAKano, K., Laboratory of Integrative Physiology in Veterinary Sciences, Osaka Prefecture University, 1-58, Rinku-ourai Kita, Izumisano, Osaka 598-8531, Japan. e-mail: takano@vet.osakafu-u.ac.jp

(C)2014 The Japanese Society of Veterinary Science

This is an open-access article distributed under the terms of the Creative Commons Attribution Non-Commercial No Derivatives (by-nc-nd) License $<$ http://creativecommons.org/licenses/by-nc-nd/3.0/>.
}

independently of the source of the infection [25], suggesting an important role for glial cells during the diseases. In an in vitro study, Tribouillard-Tanvier et al. reported that scrapie brain extract stimulated cytokine release from cultured microglia and astrocytes [29]. Additionally, it has been reported that prion-infected astrocytes markedly accelerate neurodegeneration in neuron/astrocyte co-cultures compared with an infected neuronal culture [8]. These studies suggest that the involvement of glial cells is necessary in the pathogenesis of prion diseases.

On the other hand, astrocytes and microglia are known to produce various neurotrophic factors including brain-derived neurotrophic factor (BDNF) and glial cell line-derived neurotrophic factor (GDNF) [18]. Neurotrophic factors released from astrocytes and microglia contribute to the maintenance of neuronal survival [3]. Astrocytes have been reported to increase the production of GDNF in mouse models of prion disease [13], suggesting that astrocytes may also play important roles in the repair processes of damaged neurons. On the basis of these reports, astrocytes and microglia should be important target cells for therapeutic treatments of prion diseases.

Taken together, AmB might have therapeutic effects in prion diseases through changes in glial functions. In our attempt to elucidate the therapeutic mechanisms of $\mathrm{AmB}$ in prion diseases, we previously reported that $A m B$ increased levels of GDNF mRNA in microglia and protein levels of 
BDNF and GDNF in astrocytes [20,21]. In the present study, we investigated whether AmB affected glial activation and neurotrophic factor production in vivo. We directly injected $\mathrm{AmB}$ into the rat striatum and examined the expression of neurotrophic factors.

\section{MATERIALS AND METHODS}

Reagents: Pentobarbital sodium injections $(50 \mathrm{mg} / \mathrm{m} l)$ were purchased from Dainippon Sumitomo Pharma (Osaka, Japan). Amphotericin B, anti-mitogen activated protein (MAP) 2 antibody and anti-glial fibrillary acidic protein (GFAP) antibody were obtained from Sigma-Aldrich (St. Louis, MO, U.S.A.). The AmB used in the present study was confirmed not to be contaminated with bacterial endotoxin or lipopolysaccharide by limulus test as previously described [20]. Tissue Mount was obtained from Chiba Medical (Saitama, Japan). 3,3'-Diaminobenzidine tetrahydrochloride (DAB) was obtained from Dojindo (Kumamoto, Japan). Anti-BDNF antibody was from EMD Millipore (Billerica, MA, U.S.A.). Anti-CD11b antibody was from AbD Serotec (Oxford, U.K.). Anti-GDNF antibody was from R\&D Systems (Minneapolis, MN, U.S.A.). Simple Stain Max PO (G) and Simple Stain Max PO (Multi) were obtained from Nichirei Biosciences (Tokyo, Japan). Normal goat serum and bovine serum albumin were obtained from Wako Pure Chemical Industries (Osaka, Japan). Fluorescein (FITC)-conjugated goat anti-mouse $\operatorname{IgG}(\mathrm{H}+\mathrm{L})$ antibody and Rhodamine (TRITC)-conjugated goat anti-rabbit IgG $(\mathrm{H}+\mathrm{L})$ antibody were obtained from Jackson ImmunoResearch (West Grove, PA, U.S.A.). Alexa Fluor ${ }^{\circledR}$ 568-conjugated anti-goat IgG antibody and Alexa Fluor ${ }^{\circledR}$ 488-conjugated anti-rabbit IgG antibody were obtained from Invitrogen (Carlsbad, CA, U.S.A.).

Animal treatment: The present study was carried out in compliance with the Guide for Animal Experimentation at Osaka Prefecture University. Wistar rats (male, 11 weeks of age, vehicle and AmB groups each, $\mathrm{n}=6$ ) were anesthetized with pentobarbital sodium $(50 \mathrm{mg} / \mathrm{kg}$, i.p.) and were fixed on a stereotaxic instrument. A single injection of AmB (5.0 $\mu \mathrm{g} / 5.5 \mu \mathrm{l}$ PBS, $1 \mu \mathrm{l} / \mathrm{min}$ ) was administered into the right striatum (ahead $+1 \mathrm{~mm}$, right $+3 \mathrm{~mm}$, depth $+5 \mathrm{~mm}$ from the bregma). The control group was similarly treated with vehicle ( $5.5 \mu l$ PBS containing $0.7 \mathrm{mg} / \mathrm{m} l$ sodium deoxycholate). It has been reported that intraventricular infusion of $\mathrm{AmB}(90 \mu \mathrm{g} / \mathrm{kg}$ mouse body weight/day) prolongs the onset of symptoms of transgenic mice intracerebrally infected with scrapie agent [9]. The AmB dose $(5.0 \mu \mathrm{g} / 5.5 \mu l$ PBS in the rat brain) was determined based on this reference with consideration for the rat brain weight. In prion diseases, it has been reported that dopaminergic [32] neurons are degenerated and lost; therefore, the striatum, which is easier to approach, was chosen as the administration site in the present study.

Histological analysis: Histological analysis was performed 24 or $72 \mathrm{hr}$ after AmB injection. We selected the time of $72 \mathrm{hr}$ after injection to determine the levels of protein expression in the brain parenchyma around the AmB injec-

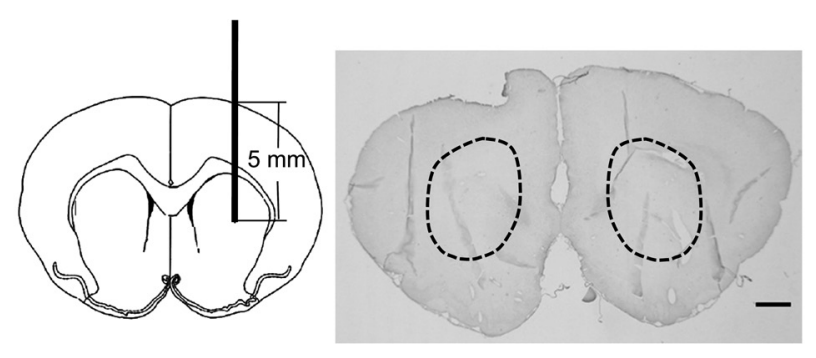

Fig. 1. The picture shows the administration site, and the photo shows a representative brain section stained with anti-GDNF antibody in the vehicle group. The circles with dashed line show the peripheral region of the right striatum around the injection site and the contralateral region used in the densitometric analysis. Scale bar $=1 \mathrm{~mm}$.

tion site including both intra- and extracellular proteins, and we selected the time of $24 \mathrm{hr}$ after injection to assess the expressing cell type. Animals were anesthetized with pentobarbital sodium, followed by transcardial perfusion with $0.9 \%$ saline and then with $4 \%$ paraformaldehyde in $0.1 \mathrm{M}$ phosphate buffer ( $\mathrm{pH} 7.4$ ). Brains were removed, postfixed for $6 \mathrm{hr}$ at $4{ }^{\circ} \mathrm{C}$ with $4 \%$ paraformaldehyde in phosphate buffer and placed in $30 \%$ sucrose in PBS for 3 days at $4^{\circ} \mathrm{C}$. The brains were embedded with tissue mount, and coronal sections were cut at a thickness of $10 \mu \mathrm{m}$ in a cryostat. Sections were air-dried and processed for immunostaining. They were treated with $0.3 \%$ Triton X-100 in PBS three times for $5 \mathrm{~min}$ at room temperature and rinsed in PBS, followed by incubation in PBS containing 3\% bovine serum albumin for GDNF or $10 \%$ normal goat serum for others (blocking solution) for $15 \mathrm{~min}$ at room temperature. The sections were then incubated with individual primary antibodies against BDNF, GDNF, GFAP and CD11b diluted in blocking solution as described below for $72 \mathrm{hr}$ at $4^{\circ} \mathrm{C}$.

For the determination of protein expression level, sections were rinsed with PBS for 5 min three times and placed in PBS containing $0.3 \%$ hydrogen peroxide and $0.065 \%$ sodium azide for $30 \mathrm{~min}$ to eliminate the activity of endogenous peroxidase. After being washed with PBS, sections were reacted with Simple Stain Max PO (G) or Simple Stain Max PO (Multi) as a secondary antibody at room temperature for $30 \mathrm{~min}$. The sections were washed again with PBS and then incubated in freshly prepared DAB solution for the appropriate period of time. After being washed in distilled water, sections were photographed, and the expression of each protein immunoreactively positive against antibodies was assessed by densitometric analysis using quantification software, Image J (NIH). The measurements were carried out in the peripheral region of the striatum around the site of injection but avoiding the trace of injection. Similarly, the contralateral regions were also measured, and the ratios of the densities were quantified (Fig. 1).

For assessment of expressing cell type, sections were reacted with fluorescence protein-conjugated secondary antibodies diluted in PBS $(1: 50)$ for $3 \mathrm{hr}$ at room temperature. After being washed with PBS, sections were observed under 
(A)

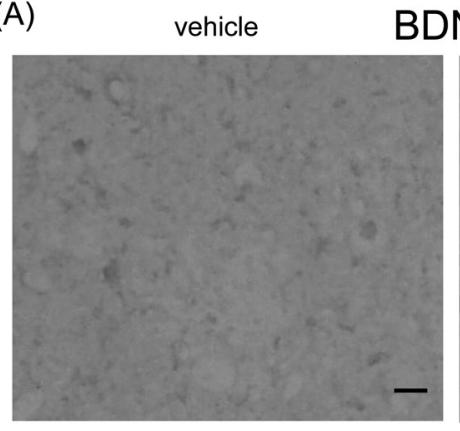

(B)

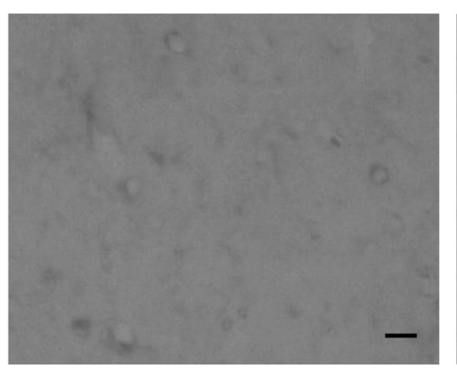

BDNF

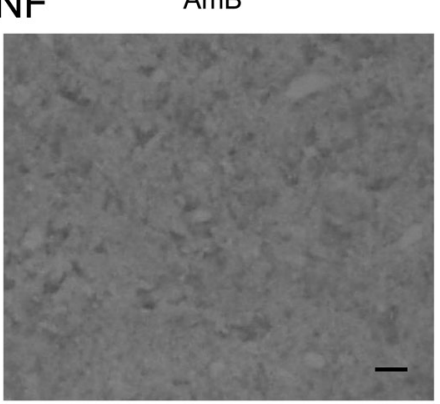

$\mathrm{AmB}$
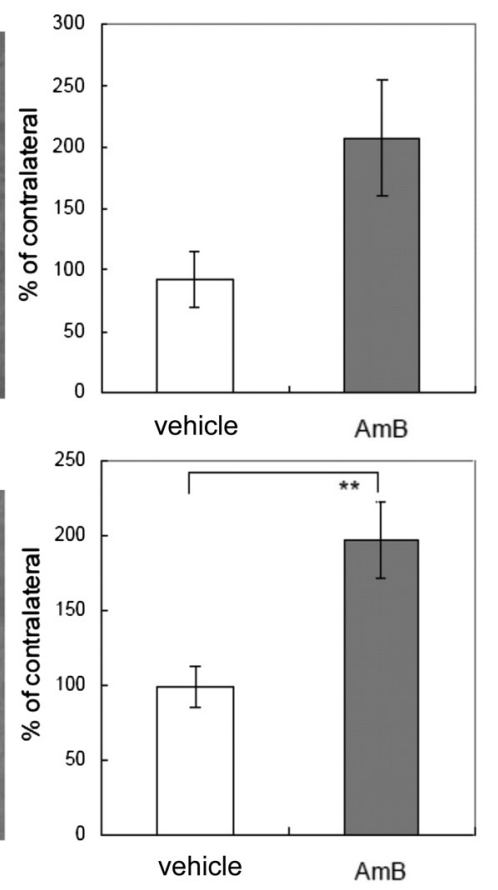

Fig. 2. AmB increased GDNF expression. Sections were immunostained with primary antibodies against BDNF (A) and GDNF (B) $72 \mathrm{hr}$ after AmB stimulation. Photos show the peripheral region of the right striatum around the injection site. Scale bar $=10 \mu \mathrm{m}$. The graphs show the ipsilateral/contralateral ratio assessed by densitometric analysis. Each value indicates the mean \pm SEM of three samples from independent experiments. $* * P<0.01$ compared with vehicle by the Student's $t$-test.

a confocal laser-scanning microscope (Nikon C1si).

The dilution ratios for primary antibodies were as follows: 1:500 (BDNF), 1:200 (GDNF), 1:5,000 (GFAP), 1:500 (CD11b) and 1:10,000 (MAP2) for determination of the protein expression level and 1:200 (BDNF), 1:10 (GDNF), 1:1,000 (GFAP) and 1:200 (CD11b) for assessment of the expressing cell type.

Data analysis: The Student's $t$-test was used for statistical analysis of the data.

\section{RESULTS}

Effects of AmB on expression of neurotrophic factor proteins: To investigate the effects of $\mathrm{AmB}$ on the production of neurotrophic factor proteins in vivo, we observed the expression of BDNF and GDNF proteins by immunohistochemical analysis after AmB injection. Amphotericin B (5.0 $\mu \mathrm{g} / \mathrm{rat})$ was injected into the right striatum in rats, and $72 \mathrm{hr}$ later, sections were immunostained with antibodies specific for BDNF and GDNF. The expression level of BDNF was not significantly increased by stimulation with $\mathrm{AmB}$ compared with the vehicle group (Fig. 2A). On the other hand, GDNF expression was significantly increased by AmB stimulation (Fig. 2B).

Effects of $A m B$ on glial activation: We had previously reported in cultured microglia [20] and astrocytes [21] that $\mathrm{AmB}$ could stimulate NO production and change the expression levels of mRNAs of proinflammatory cytokines and neurotrophic factors. To investigate the effects of AmB on glial activation in vivo, we observed the expression of GFAP, an astrocyte marker, and CD11b, a microglial marker, by immunohistochemical analysis after AmB injection. Amphotericin B $(5.0 \mu \mathrm{g} / \mathrm{rat})$ was injected into the right striatum in rats, and $72 \mathrm{hr}$ later, sections were immunostained with antibodies specific for GFAP and CD11b. The expression level of GFAP was significantly increased by stimulation with AmB compared with the vehicle group (Fig. 3A). Similarly, CD11b expression was also significantly increased by AmB stimulation (Fig. 3B).

The expression of MAP2, a neuronal marker, around the AmB injection site significantly increased compared with the vehicle group (data not shown).

Co-localization of neurotrophic factor proteins and glial marker proteins: After AmB injection, GDNF expression increased, and the expressions of GFAP and CD11b also increased. To investigate whether the expressions of BDNF and GDNF were derived from glial cells, we assessed the colocalization of BDNF and GDNF expressions with glial cell marker proteins, GFAP and CD11b. BDNF and GDNF are secreted proteins; therefore, the time point of $24 \mathrm{hr}$ after AmB injection was selected to assess the co-localization with cell markers, which was earlier than that used for determination of protein expression level in the brain. Amphotericin B (5.0 $\mu \mathrm{g} / \mathrm{rat}$ ) was injected into the right striatum in rats, and $24 \mathrm{hr}$ 
(A)

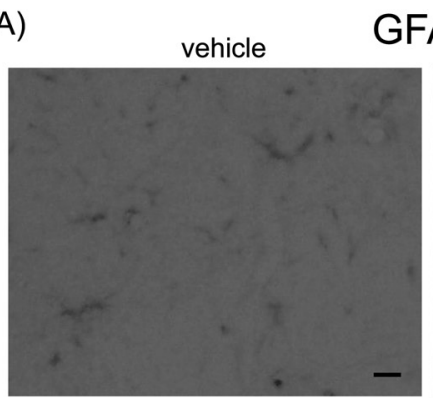

GFAP

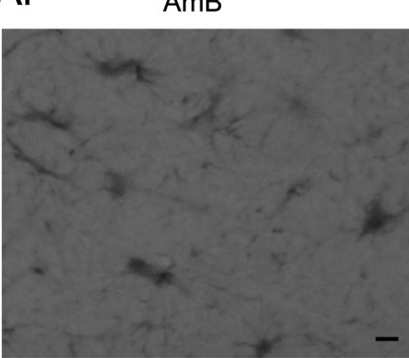

(B)

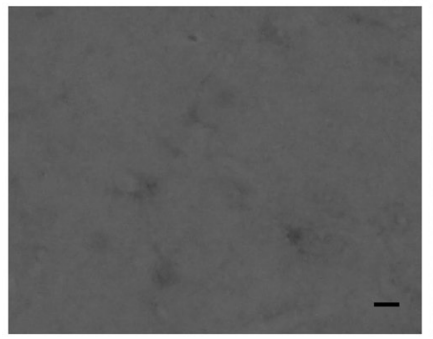

CD11b

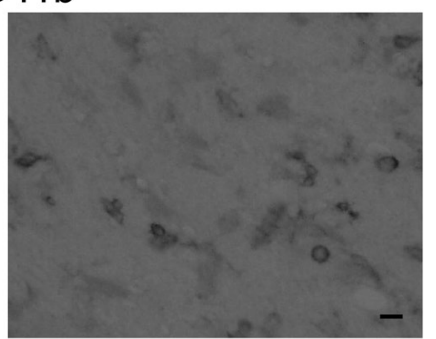

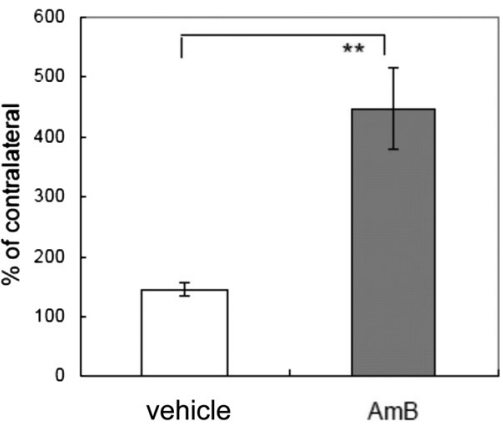

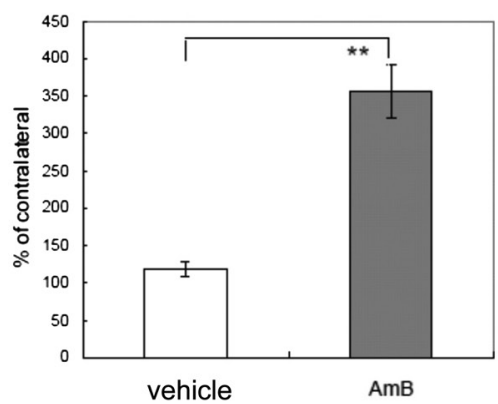

Fig. 3. AmB increased GFAP and CD11b expressions. Sections were immunostained with primary antibodies against GFAP (A) and CD11b (B) $72 \mathrm{hr}$ after AmB stimulation. Photos show the peripheral region of the right striatum around the injection site. Scale bar $=10 \mu \mathrm{m}$. The graphs show the ipsilateral/contralateral ratio assessed by densitometric analysis. Each value indicates the mean \pm SEM of three samples from independent experiments. $* * P<0.01$ compared with vehicle by the Student's $t$-test.

later, sections were double stained with antibodies against neurotrophic factor proteins and glial cell marker proteins.

In the vehicle group, cells co-expressing BDNF and glial cell marker, GFAP (Fig. 4A) and CD11b (Fig. 4B), were hardly detected. In the AmB-injected group, cells coexpressing BDNF/GFAP (Fig. 4A) and also co-expressing BDNF/CD11b (Fig. 4B) could be detected. On the other hand, cells co-expressing GDNF/GFAP (Fig. 5A) were detected in small numbers in the vehicle group. After stimulation with AmB, cells co-expressing GDNF/CD11b (Fig. 5B) as well as GDNF/GFAP (Fig. 5A) could be clearly detected.

\section{DISCUSSION}

In an in vitro study, we previously reported that $\mathrm{AmB}$ changed the expression of neurotrophic factors in astrocytes [21] and microglia [20]. In AmB-stimulated astrocytes, the expression levels of both BDNF and GDNF proteins were significantly upregulated, and the cellular amounts of neurotrophin-3 protein decreased [21]. Also, in microglia, AmB stimulation increased the expression levels of BDNF and GDNF mRNAs [20]. In the present study, we investigated whether AmB has similar effects on glial cells in vivo, not just in cell cultures in vitro. Injection of $\mathrm{AmB}$ into the right striatum of the adult rat brain increased the expression level of GDNF after $72 \mathrm{hr}$. The expressions of GFAP and CD11b were also increased at $72 \mathrm{hr}$ after $\mathrm{AmB}$ injection, and the expressions of BDNF and GDNF proteins at $24 \mathrm{hr}$ after
AmB injection were co-localized with the expressions of both GFAP and CD11b; suggesting that administration of AmB activated both astrocytes and microglia, resulting in production of BDNF and GDNF. In the present study, BDNF expression at $72 \mathrm{hr}$ after AmB stimulation was not significantly increased differently from in vitro assay. Astrocytes and microglia could express BDNF protein, because BDNF expression was co-localized with the expressions of GFAP and $\mathrm{CD} 1 \mathrm{lb}$ at $24 \mathrm{hr}$ after AmB stimulation; however, further investigations of the injection method and neuronal changes are needed in vivo.

Activation of astrocytes or microglia has been reported to protect injured neurons through the production of cytokines or neurotrophic factors in vivo [3, 11, 14]. The increase in GFAP expression is known as one of the indices of astrocyte activation and reactive gliosis $[7,16,26]$. In prion diseases, it has been reported that intense reactive gliosis is observed throughout the affected CNS region [27]. In the present study, the expression of GFAP was significantly increased by $\mathrm{AmB}$ injection. However, it has been reported that AmB inhibited gliosis in the brain of scrapie-infected hamsters [1]. In prion diseases, $\mathrm{AmB}$ injected into the brain might exert different effects on the expression of GFAP in astrocytes, because the GFAP expression in scrapie-infected astrocytes might already be increased before injection of $\mathrm{AmB}$. The effects of AmB on glial activation in the presence of PrPsc remain to be confirmed.

There are several previous reports on the working mecha- 


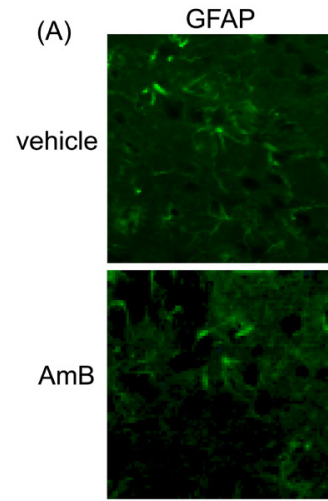

(B)
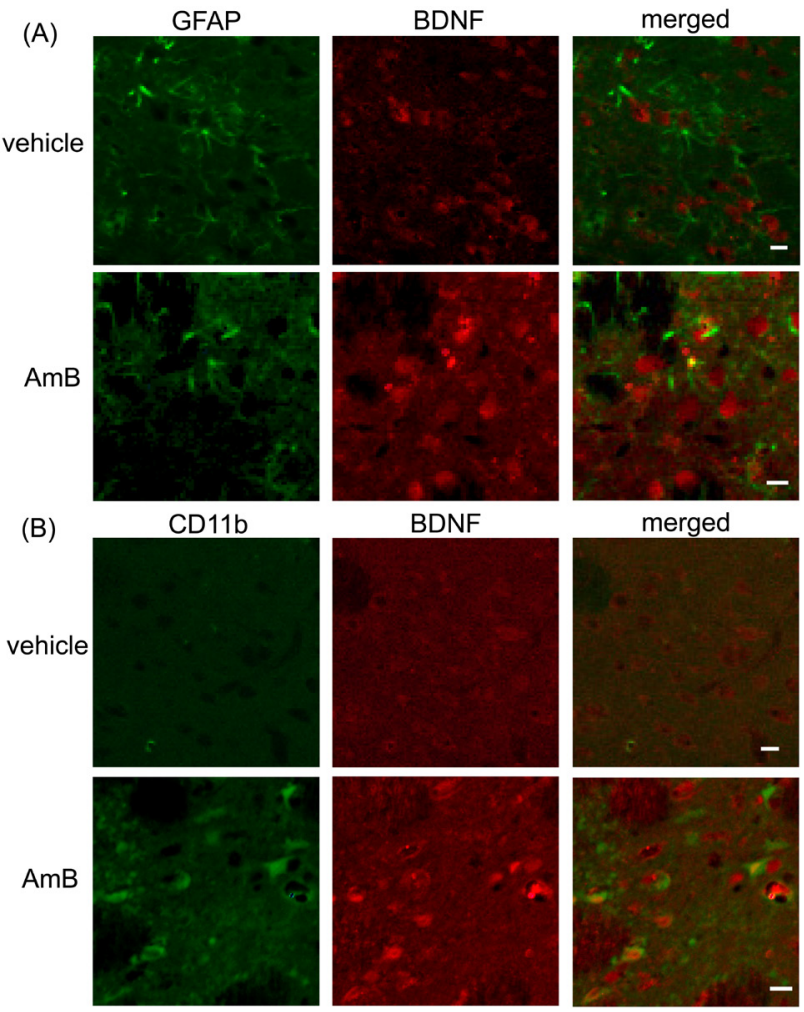

BDNF

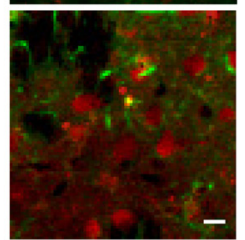

merged
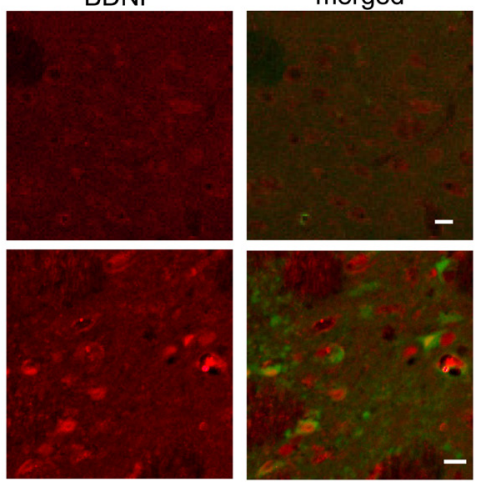

Fig. 4. Co-localization of BDNF and glial cell markers. Sections were double stained with primary antibodies against BDNF and GFAP (A) or BDNF and CD11b (B) $24 \mathrm{hr}$ after AmB stimulation. Photos show the peripheral region of the right striatum around the injection site. Scale bar $=10 \mu \mathrm{m}$.

nisms of $A m B[10,17]$. It has been reported that $A m B$ induces nuclear factor kappa $\mathrm{B}(\mathrm{NF}-\kappa \mathrm{B})$ activation through the Toll-like receptors and CD14 [19] and that the production of GDNF protein is upregulated through the activation of $\mathrm{NF}-\kappa \mathrm{B}[24,28]$. Therefore, activation of NF- $\kappa \mathrm{B}$ might be involved in the AmB-increased expression of neurotrophic factor.

It is known that both BDNF and GDNF are physiologically expressed in neurons of the striatum [2, 5]. However, when the striatum was injured by physical stimuli [3] or by drug administration [5] and the productions in neurons were reduced, expressions of BDNF and GDNF were induced in astrocytes and/or microglia [23]. In addition, GDNF has been reported to promote neuronal survival, particularly in the case of dopaminergic neurons [15]. The enhanced expression of GDNF caused by AmB injection in the present study might also have a beneficial effect on neurological failure in various neurodegenerative diseases as well as prion diseases. Our results provide new insight into the therapeutic mechanism of action of AmB.

ACKNOWLEDGMENT. This work was supported in part by a grant for the Adaptable and Seamless Technology Transfer Program through Target-driven R\&D to K.T. from
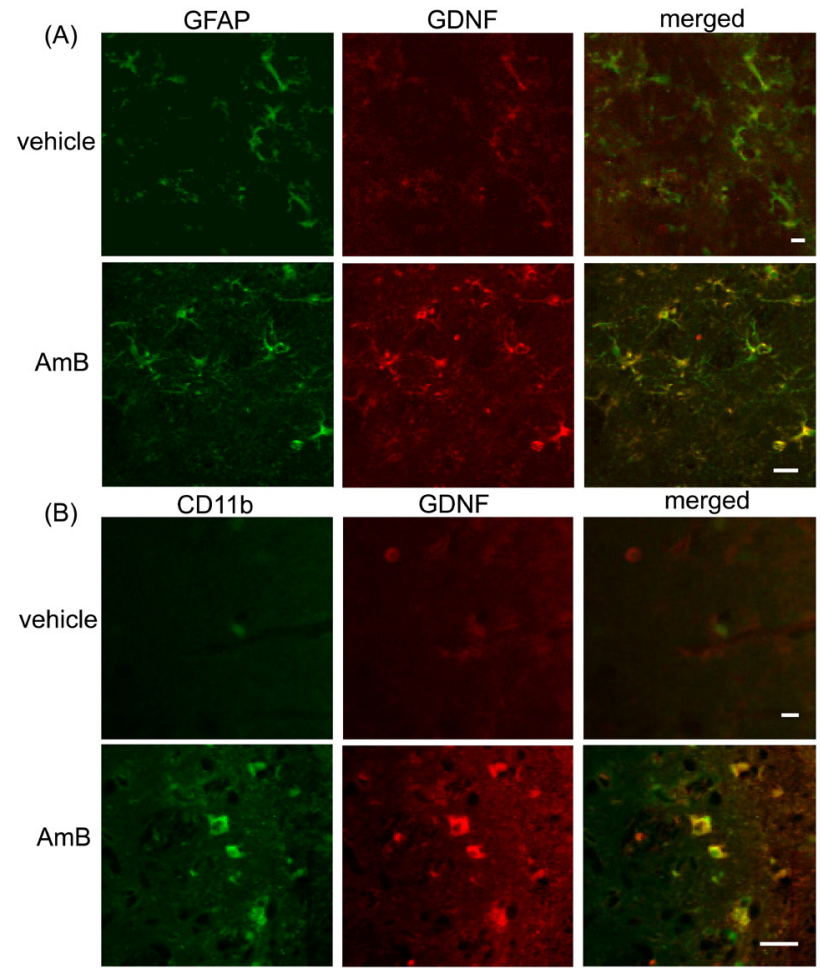

GDNF

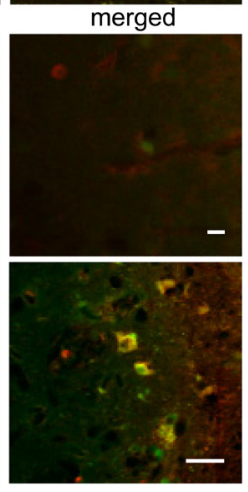

Fig. 5. Co-localization of GDNF and glial cell markers. Sections were double stained with primary antibodies against GDNF and GFAP (A) or GDNF and CD11b (B) $24 \mathrm{hr}$ after AmB stimulation. Photos show the peripheral region of the right striatum around the injection site. Scale bar $=10 \mu \mathrm{m}$.

the Japan Science and Technology Agency and by Grants-inAid for Scientific Research (24621008 to Y.N. and 23580408 to M.M.) from the Ministry of Education, Culture, Sports, Science and Technology of Japan.

\section{REFERENCES}

1. Adjou, K. T., Privat, N., Demart, S., Deslys, J. P., Seman, M., Hauw, J. J. and Dormont, D. 2000. MS-8209, an amphotericin B analogue, delays the appearance of spongiosis, astrogliosis and PrPres accumulation in the brain of scrapie-infected hamsters. $J$. Comp. Pathol. 122: 3-8. [Medline] [CrossRef]

2. Altar, C. A., Cai, N., Bliven, T., Juhasz, M., Conner, J. M., Acheson, A. L., Lindsay, R. M. and Wiegand, S. J. 1997. Anterograde transport of brain-derived neurotrophic factor and its role in the brain. Nature 389: 856-860. [Medline] [CrossRef]

3. Batchelor, P. E., Liberatore, G. T., Wong, J. Y., Porritt, M. J., Frerichs, F., Donnan, G. A. and Howells, D. W. 1999. Activated macrophages and microglia induce dopaminergic sprouting in the injured striatum and express brain-derived neurotrophic factor and glial cell line-derived neurotrophic factor. J. Neurosci. 19: 1708-1716. [Medline]

4. Brajtburg, J., Powderly, W. G., Kobayashi, G. S. and Medoff, G. 1990. Amphotericin B: current understanding of mechanisms of action. Antimicrob. Agents Chemother. 34: 183-188. [Medline] [CrossRef]

5. Bresjanac, M. and Antauer, G. 2000. Reactive astrocytes of the 
quinolinic acid-lesioned rat striatum express GFRalphal as well as GDNF in vivo. Exp. Neurol. 164: 53-59. [Medline] [CrossRef]

6. Brown, D. R., Schmidt, B. and Kretzschmar, H. A. 1996. A neurotoxic prion protein fragment enhances proliferation of microglia but not astrocytes in culture. Glia 18: 59-67. [Medline] [CrossRef]

7. Cheng, H. W., Jiang, T., Brown, S. A., Pasinetti, G. M., Finch, C. E. and McNeill, T. H. 1994. Response of striatal astrocytes to neuronal deafferentation: an immunocytochemical and ultrastructural study. Neuroscience 62: 425-439. [Medline] [CrossRef]

8. Cronier, S., Carimalo, J., Schaeffer, B., Jaumain, E., Béringue, V., Miquel, M. C., Laude, H. and Peyrin, J. M. 2012. Endogenous prion protein conversion is required for prion-induced neuritic alterations and neuronal death. FASEB J. 26: 3854-3861. [Medline] [CrossRef]

9. Doh-ura, K., Ishikawa, K., Murakami-Kubo, I., Sasaki, K., Mohri, S., Race, R. and Iwaki, T. 2004. Treatment of transmissible spongiform encephalopathy by intraventricular drug infusion in animal models. J. Virol. 78: 4999-5006. [Medline] [CrossRef]

10. Hartsel, S. C. and Weiland, T. R. 2003. Amphotericin B binds to amyloid fibrils and delays their formation: a therapeutic mechanism? Biochemistry 42: 6228-6233. [Medline] [CrossRef]

11. Imai, F., Suzuki, H., Oda, J., Ninomiya, T., Ono, K., Sano, H. and Sawada, M. 2007. Neuroprotective effect of exogenous microglia in global brain ischemia. J. Cereb. Blood Flow Metab. 27: 488-500. [Medline] [CrossRef]

12. Kretzschmar, H. A., Prusiner, S. B., Stowring, L. E. and DeArmond, S. J. 1986. Scrapie prion proteins are synthesized in neurons. Am. J. Pathol. 122: 1-5. [Medline]

13. Lee, Y. J., Jin, J. K., Jeong, B. H., Carp, R. I. and Kim, Y. S. 2006. Increased expression of glial cell line-derived neurotrophic factor (GDNF) in the brains of scrapie-infected mice. Neurosci. Lett. 410: 178-182. [Medline] [CrossRef]

14. Liberto, C. M., Albrecht, P. J., Herx, L. M., Yong, V. W. and Levison, S. W. 2004. Pro-regenerative properties of cytokineactivated astrocytes. J. Neurochem. 89: 1092-1100. [Medline] [CrossRef]

15. Lin, L. F., Doherty, D. H., Lile, J. D., Bektesh, S. and Collins, F. 1993. GDNF: a glial cell line-derived neurotrophic factor for midbrain dopaminergic neurons. Science 260: 1130-1132. [Medline] [CrossRef]

16. Loos, M., Dihné, M. and Block, F. 2003. Tumor necrosis factoralpha expression in areas of remote degeneration following middle cerebral artery occlusion of the rat. Neuroscience 122: 373-380. [Medline] [CrossRef]

17. Mangé, A., Nishida, N., Milhavet, O., McMahon, H. E., Casanova, D. and Lehmann, S. 2000. Amphotericin B inhibits the generation of the scrapie isoform of the prion protein in infected cultures. J. Virol. 74: 3135-3140. [Medline] [CrossRef]

18. Merrill, J. E. and Jonakait, G. M. 1995. Interactions of the nervous and immune systems in development, normal brain homeostasis, and disease. FASEB J. 9: 611-618. [Medline]

19. Mesa-Arango, A. C., Scorzoni, L. and Zaragoza, O. 2012. It only takes one to do many jobs: Amphotericin B as antifungal and immunomodulatory drug. Front. Microbiol. 3: 286. [Medline] [CrossRef]

20. Motoyoshi, A., Nakajima, H., Takano, K., Moriyama, M., Kannan, Y. and Nakamura, Y. 2008. Effects of Amphotericin B on the expression of neurotoxic and neurotrophic factors in cultured microglia. Neurochem. Int. 52: 1290-1296. [Medline] [CrossRef]

21. Motoyoshi-Yamashiro, A., Tamura, M., Moriyama, M., Takano, K., Kawabe, K., Nakajima, H., Katoh-Semba, R., Furuichi, T. and Nakamura, Y. 2013. Activation of cultured astrocytes by amphotericin B: stimulation of $\mathrm{NO}$ and cytokines production and changes in neurotrophic factors production. Neurochem. Int. 63: 93-100. [Medline] [CrossRef]

22. Pocchiari, M., Schmittinger, S. and Masullo, C. 1987. Amphotericin B delays the incubation period of scrapie in intracerebrally inoculated hamsters. J. Gen. Virol. 68: 219-223. [Medline] [CrossRef]

23. Saavedra, A., Baltazar, G. and Duarte, E. P. 2008. Driving GDNF expression: the green and the red traffic lights. Prog. Neurobiol. 86: 186-215. [Medline] [CrossRef]

24. Saha, R. N., Liu, X. and Pahan, K. 2006. Up-regulation of BDNF in astrocytes by TNF-alpha: a case for the neuroprotective role of cytokine. J. Neuroimmune Pharmacol. 1: 212-222. [Medline] [CrossRef]

25. Sarasa, R., Martínez, A., Monleón, E., Bolea, R., Vargas, A., Badiola, J. J. and Monzón, M. 2012. Involvement of astrocytes in transmissible spongiform encephalopathies: a confocal microscopy study. Cell Tissue Res. 350: 127-134. [Medline] [CrossRef]

26. Schauwecker, P. E., Cogen, J. P., Jiang, T., Cheng, H. W., Collier, T. J. and McNeill, T. H. 1998. Differential regulation of astrocytic mRNAs in the rat striatum after lesions of the cortex or substantia nigra. Exp. Neurol. 149: 87-96. [Medline] [CrossRef]

27. Sofroniew, M. V. and Vinters, H. V. 2010. Astrocytes: biology and pathology. Acta Neuropathol. 119: 7-35. [Medline] [CrossRef]

28. Tanabe, K., Nishimura, K., Dohi, S. and Kozawa, O. 2009. Mechanisms of interleukin-1beta-induced GDNF release from rat glioma cells. Brain Res. 1274: 11-20. [Medline] [CrossRef]

29. Tribouillard-Tanvier, D., Striebel, J. F., Peterson, K. E. and Chesebro, B. 2009. Analysis of protein levels of 24 cytokines in scrapie agent-infected brain and glial cell cultures from mice differing in prion protein expression levels. J. Virol. 83 : 11244-11253. [Medline] [CrossRef]

30. Williams, A. E., Lawson, L. J., Perry, V. H. and Fraser, H. 1994. Characterization of the microglial response in murine scrapie. Neuropathol. Appl. Neurobiol. 20: 47-55. [Medline] [CrossRef]

31. Williams, A., Van Dam, A. M., Ritchie, D., Eikelenboom, P. and Fraser, H. 1997. Immunocytochemical appearance of cytokines, prostaglandin E2 and lipocortin-1 in the CNS during the incubation period of murine scrapie correlates with progressive PrP accumulations. Brain Res. 754: 171-180. [Medline] [CrossRef]

32. Yun, S. W., Choi, E. K., Ju, W. K., Ahn, M. S., Carp, R. I., Wisniewski, H. M. and Kim, Y. S. 1998. Extensive degeneration of catecholaminergic neurons to scrapie agent $87 \mathrm{~V}$ in the brains of IM mice. Mol. Chem. Neuropathol. 34: 121-132. [Medline] [CrossRef] 